Proc. Estonian Acad. Sci. Geol., 1998, 47, 2, 86-107

\title{
THE PITKASOO BOG - AN ANCYLUS LAGOON FROM SAAREMAA ISLAND, ESTONIA
}

\author{
Lars-König KÖNIGSSON ${ }^{\mathrm{a}}$, Leili SAARSE ${ }^{\mathrm{b}}$, and Göran POSSNERT ${ }^{\mathrm{c}}$
}

a Institute of Earth Sciences, Quaternary Geology, Norbyvägen 18B, S-75236 Uppsala, Sweden; e-mail: lars-konig.konigsson@natgeog.uu.se

b Institute of Geology at Tallinn Technical University, Estonia pst. 7, EE-0001 Tallinn, Estonia; e-mail: saarse@gi.ee

c Tandem Laboratory, Institute of Physics, Box 534, S-751 21, Uppsala, Sweden; e-mail: goran.possnert@tsl.uu.se

Received 12 November 1997

Abstract. Two interchanging gyttja-peat sequences were investigated in the basal parts of the Pitkasoo Bog, Saaremaa Island, Estonia. These are interpreted to represent ingressions or ground water rises around $9800 \pm 80 \mathrm{BP}$, depending on water level changes in the Yoldia Sea. An early part of the Ancylus transgression, which occurs earlier than the immigration of Alnus to Saaremaa, was also distinguished. The Pitkasoo sequences offer interesting possibilities for the study of the early stages of the Yoldia succession.

Key words: stratigraphy, pollen analysis, ${ }^{14} \mathrm{C}$ AMS-date, Yoldia, Ancylus.

\section{INTRODUCTION}

The Baltic Sea history has been intensively investigated in Estonia over the last 40 years (Kessel, 1961, 1988; Haila \& Raukas, 1992; Kessel \& Raukas, 1967, 1979; Raukas, 1994, 1995). Numerous studies of peat deposits underlying beach ridges, mainly dealing with pollen, molluscs, and radiocarbon dates, appeared during the 1960s and 1970s (Kessel \& Raukas, 1967, 1979; Kessel \& Punning, 1969). The biphasic transgression of the Yoldia Sea with an amplitude of several metres was suggested but was rejected lately (Lepland et al., 1995; Raukas, 1994, 1995; Saarse et al., 1997). The Pitkasoo Bog was selected for the study because of its position behind an Ancylus beach ridge to get new information on the character and duration of the Yoldia and Ancylus phases on Saaremaa. The results are connected with the development of the Yoldia Sea and the early part of the Ancylus Lake. 
The Pitkasoo area has been examined twice; its biostratigraphy and beach formations have been briefly described (Kessel \& Raukas, 1967; Saarse \& Königsson, 1992; Poska, 1994; Saarse et al., 1994). According to the earlier interpretation, during the second half of the Early Boreal a lagoon was formed behind the Ancylus spit which later on became an isolated lake (Kessel \& Raukas, 1967).

During reconnaissance coring in 1991 we found buried organic deposits below Ancylus transgressional silts. This makes Pitkasoo especially attractive among sites providing information about the Baltic Sea history (Saarse et al., 1994; Poska, 1994).

\section{GEOLOGICAL SETTING}

Pitkasoo (Kääsla) is an ancient Ancylus lagoon, now a small elongated bog on the SE slope of the West Saaremaa Upland, about $20 \mathrm{~km}$ west of the town of Kuressaare (Fig. 1). It is $1400 \mathrm{~m}$ long and $300 \mathrm{~m}$ wide, c. 30 ha in area at an elevation of about $25 \mathrm{~m}$ a.s.l. The bog has been drained and reclaimed agri-

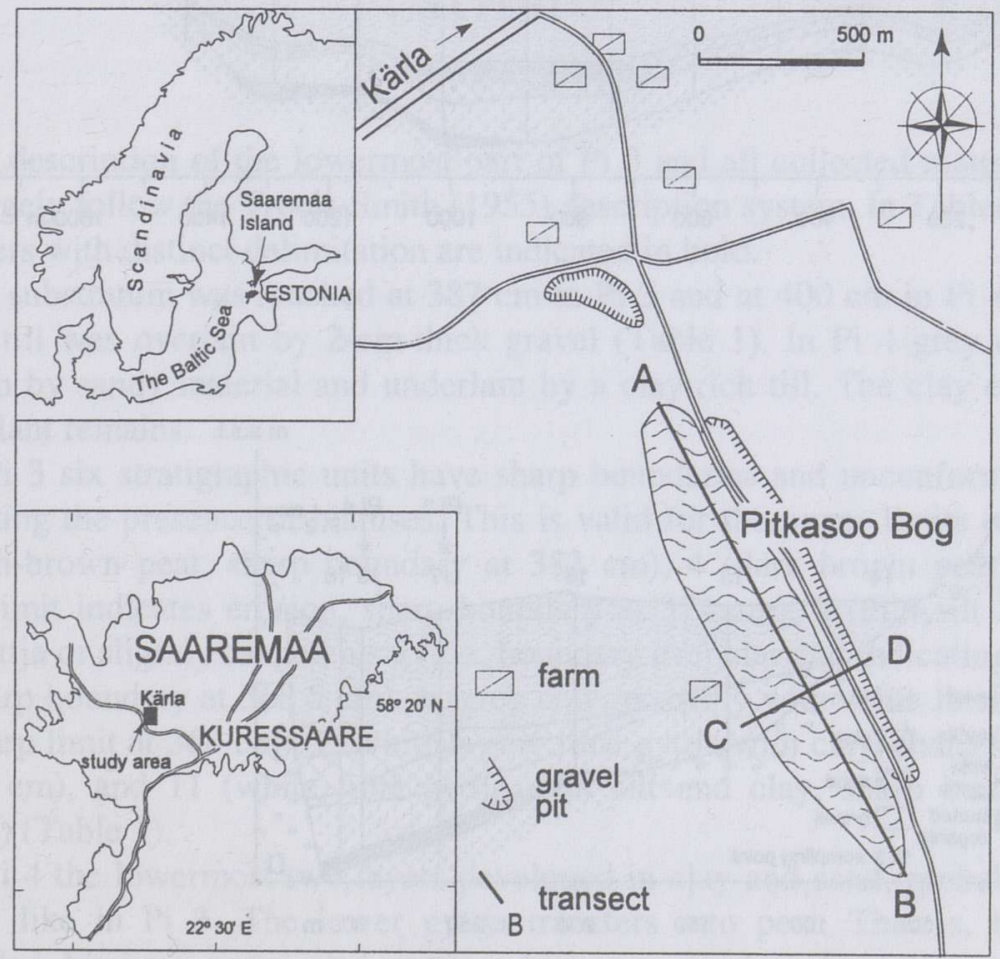

Fig. 1. Location of the Pitkasoo Bog with indication of the sampling points. 
culturally. Outflow brooks are absent and water infiltrates through the damming beach ridge and reaches the surface as springs on the eastern slopes of the upland.

The Ancylus spit borders Pitkasoo in the east. Before the Ancylus transgression a glaciofluvial ridge existed in the present place of the Ancylus spit. The structure and texture of the ridge are exposed in a gravel pit in the NW part of the spit: basal glaciofluvial sand and gravel are covered there by c. 3-m-thick beach deposits. The top of the spit has been levelled to $30 \mathrm{~m}$ a.s.1. The study area lies close to the $32 \mathrm{~m}$ isobase corresponding to the highest level of the Yoldia Sea and the $30 \mathrm{~m}$ isobase of the Ancylus Lake (Kessel \& Raukas, 1979). The initial pre-Ancylus threshold of Pitkasoo at $27.5 \mathrm{~m}$ lies about $4.5 \mathrm{~m}$ below the Yoldia and $2.5 \mathrm{~m}$ below the Ancylus maximum limits.

We made the stratigraphic sections (cores 17, 18, and 19) from the deepest part of the bog (Fig. 2). The buried peaty deposits form a lens behind the Ancylus beach ridge and are covered by clayey deposits which can be followed in almost
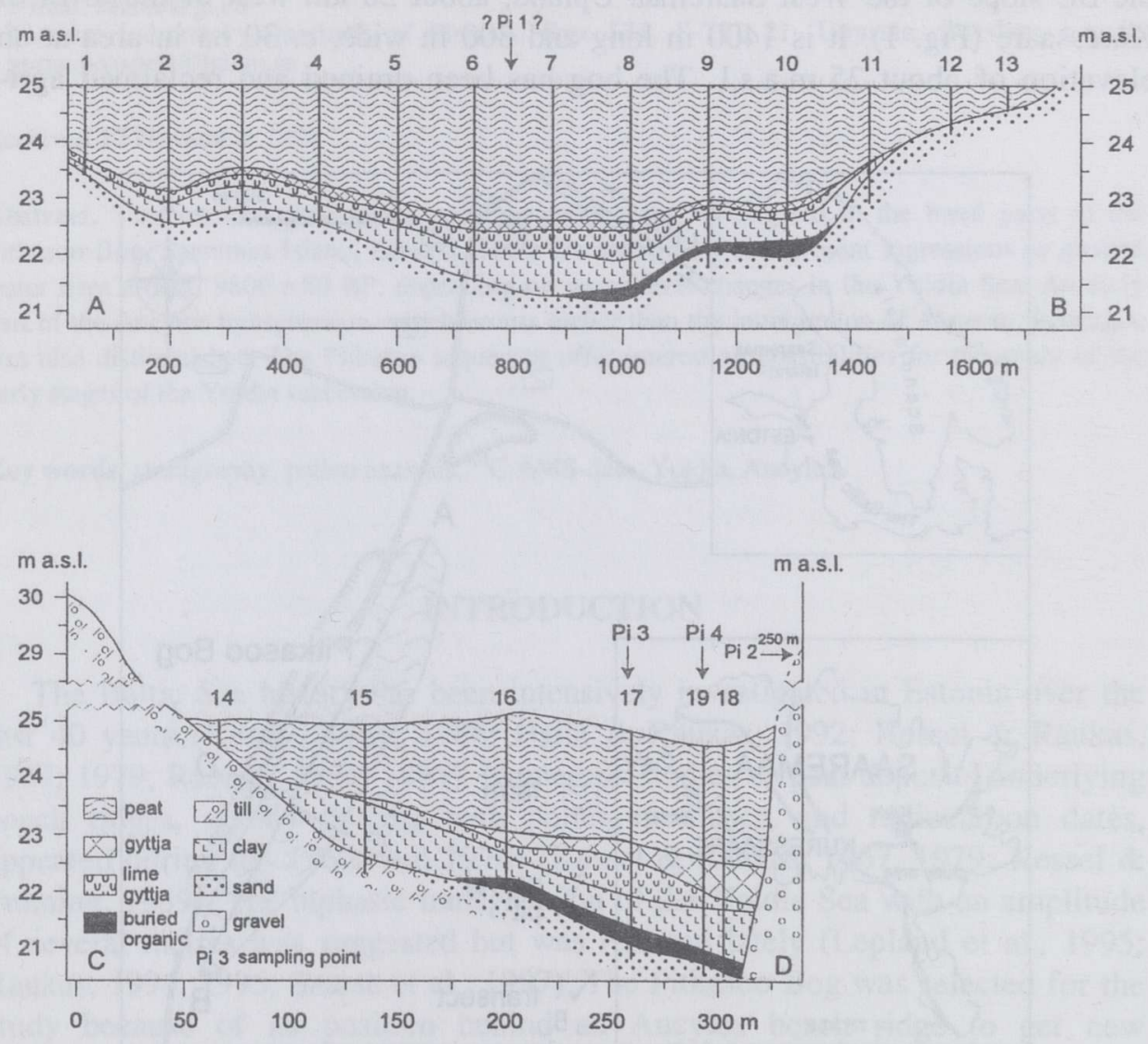

Fig. 2. Transects A-B and C-D through the Pitkasoo Bog. Sampling points $\mathrm{Pi} 1$ and $\mathrm{Pi} 2$ will be treated in Königsson \& Poska (in press). 
the whole basin. This lowermost part of the section is discussed in the present paper. The main part of the Pitkasoo core will be described in a separate paper (Königsson \& Poska, in press).

\section{METHODS}

Two transects were cored with a Belarus peat auger (Figs. 1 and 2). Samples from cores 17 (Pitkasoo 3 - Pi 3) and 19 (Pitkasoo 4 - Pi 4) were studied for pollen and diatoms. For Pi 3 and $\mathrm{Pi} 4$ full and combination diagrams have been compiled. One sample of the buried peat was dated by the accelerator mass spectrometry (AMS) techniques in the Tandem Laboratory at Uppsala University. Gyttja and the uppermost peat were dated by A. Liiva at the University of Tartu, using conventional radiocarbon dating techniques. These dates are discussed in another paper (Königsson \& Poska, in press). The principles of the reconstruction of the diagrams are presented in Königsson et al., 1998.

\section{MATERIAL}

\section{Lithostratigraphy}

The description of the lowermost part of $\mathrm{Pi} 3$ and all collected material from Pi 4 largely follow the Troels-Smith (1955) description system. In Tables 1 and 2 the layers with distinct delimitation are indicated in bold.

The substratum was reached at $387 \mathrm{~cm}$ in Pi 3 and at $400 \mathrm{~cm}$ in Pi 4 . In Pi 3 clayey till was overlain by 2 -cm-thick gravel (Table 1 ). In Pi 4 grey clay was overlain by sandy material and underlain by a clay-rich till. The clay contained some plant remains.

In Pi 3 six stratigraphic units have sharp boundaries and unconformities are suggesting the presence of hiatuses. This is valid for the upper limits of units 2 (greyish-brown peat, sharp boundary at $383 \mathrm{~cm}$ ), 4 (dark brown peat, uneven upper limit indicates erosion, sharp boundary at $374 \mathrm{~cm}$ ), 5 (thin silt layers in clay gyttja or slightly calcareous gyttja, boundary irregular and indicating erosion (?), sharp boundary at $368.5 \mathrm{~cm}$ ), 6 (grey clay, possibly with some lime, uneven and sharp limit at $368 \mathrm{~cm}$ ), 7 (whitish-grey lime gyttja with clay, sharp boundary at $367 \mathrm{~cm}$ ), and 11 (white lime gyttja with silt and clay, sharp boundary at $355 \mathrm{~cm}$ ) (Table 1).

In Pi 4 the lowermost two layers developed in clay and sand, probably lying on tills like in $\mathrm{Pi}$ 3. The lower gyttja transfers into peat. That is, however, succeeded by lime gyttja and gyttja which are overlain by two peat layers separated by another gyttja. Both these layers are very thin and contain assembled peat detritus rather than being peat layers sensu stricto (Table 2). 
The lithostratigraphy of the Pitkasoo 3 section (core 17)

\begin{tabular}{|c|c|c|c|}
\hline Unit & Boundaries, $\mathrm{cm}$ & Upper limit & Comments \\
\hline \multicolumn{4}{|c|}{ Substratum: clay-containing till $(389 \mathrm{~cm}+)$ covered by gravel $(389-387 \mathrm{~cm})$} \\
\hline 1 & $387-385$ & Gradual, $\pm 10 \mathrm{~mm}$ & Olive-grey, silty to sandy gyttja \\
\hline 2 & $385-383$ & Sharp, $\pm 1 \mathrm{~mm}$ & $\begin{array}{l}\text { Greyish-brown peat with wood fragments and } \\
\text { gyttja particles }\end{array}$ \\
\hline 3 & $383-380$ & Gradual & Dark olive-grey gyttja with some silt \\
\hline 4 & $380-374$ & Sharp, $\pm 1 \mathrm{~mm}$ & $\begin{array}{l}\text { Dark brown peat with the uneven upper } \\
\text { boundary, indicating early erosion }\end{array}$ \\
\hline 5 & $374-368.5$ & Sharp, $\pm 1 \mathrm{~mm}$ & $\begin{array}{l}\text { Thin silt layers in clay gyttja or slightly } \\
\text { calcareous gyttja. The boundary is uneven, } \\
\text { indicating erosion }\end{array}$ \\
\hline 6 & $368.5-368$ & Sharp, $\pm 1 \mathrm{~mm}$ & $\begin{array}{l}\text { Grey clay, possibly with some lime. The } \\
\text { boundary is uneven (erosion?) }\end{array}$ \\
\hline 7 & $368-367$ & Sharp, $\pm 1 \mathrm{~mm}$ & Whitish-grey lime gyttja with clay \\
\hline 8 & $367-363$ & Gradual & Plumbum-grey clay with dark dots \\
\hline 9 & $363-361.5$ & Gradual & Plumbum-grey clay without dark dots \\
\hline 10 & $361.5-360$ & $>1 \mathrm{~mm}<10 \mathrm{~mm}$ & Plumbum-grey clay with dark dots \\
\hline 11 & $360-355$ & Sharp, $\pm 1 \mathrm{~mm}$ & White lime gyttja with silt and clay \\
\hline 12 & $355-309$ & $\pm 2 \mathrm{~mm}$ & $\begin{array}{l}\text { Well-layered clay with lime gyttja in almost } \\
\text { cyclotheme structures. Very sharp boundaries } \\
\text { between the interchanging layers }\end{array}$ \\
\hline
\end{tabular}

Table 2

The lithostratigraphy of the Pitkasoo 4 section (core 19)

\begin{tabular}{|c|c|c|c|}
\hline Unit & Boundaries, $\mathrm{cm}$ & Upper limit & Comments \\
\hline \multicolumn{4}{|c|}{ Substratum: clay-rich till } \\
\hline 1 & $400-390$ & $>0 \mathrm{~mm}$ & Grey clay with plant remains \\
\hline 2 & $390-387$ & $>10 \mathrm{~mm}$ & Brown sand without visible plant remains \\
\hline 3 & $387-383$ & $<10 \mathrm{~mm}$ & $\begin{array}{l}\text { Blackish-brown gyttja, downwards silty to sandy } \\
\text { and with calcareous reaction }\end{array}$ \\
\hline 4 & $383-378.5$ & Sharp, $>1 \mathrm{~mm}$ & $\begin{array}{l}\text { Blackish-brown, heavily decomposed and } \\
\text { compressed peat, possibly peaty gyttja with silt }\end{array}$ \\
\hline 5 & $378.5-374.5$ & Sharp, > $1 \mathrm{~mm}$ & Upwards darker, olive-green lime gyttja \\
\hline 6 & $374.5-373.5$ & $<1 \mathrm{~mm}$ & $\begin{array}{l}\text { Gyttja with interacting bands in olive-green and } \\
\text { whitish-grey shades }\end{array}$ \\
\hline 7 & $373.5-373.2$ & Sharp, $<1 \mathrm{~mm}$ & Grey-brown peat or assembled peat detritus \\
\hline 8 & $373.2-372.0$ & Sharp, $<1 \mathrm{~mm}$ & White calcareous gyttja \\
\hline 9 & $372.0-371.5$ & Sharp, $<1 \mathrm{~mm}$ & Grey-brown peat or assembled peat detritus \\
\hline 10 & $371.5-370.5$ & Sharp, $\pm 1 \mathrm{~mm}$ & Olive-grey calcareous gyttja \\
\hline 11 & $370.5-368$ & $>1 \mathrm{~mm}$ & Dark grey lime gyttja with silt and Characeae bands \\
\hline 12 & $368-366$ & Very sharp & $\begin{array}{l}\text { Grey, partly calcareous gyttja with silt and } \\
\text { Characeae bands }\end{array}$ \\
\hline 13 & $366-364$ & - & Whitish-grey sand and silt \\
\hline
\end{tabular}


In Pi 4 signs of erosion were recorded in units 4 (blackish-brown, heavily decomposed, very compressed peat, sharp boundary at $378.5 \mathrm{~cm}$ ), 5 (olive-green lime gyttja with silt and sand particles, very compressed, sharp boundary at $374.5 \mathrm{~cm}$ ), 7 (grey-brown peat or assembled peat detritus, sharp boundary at $373.2 \mathrm{~cm}$ ), 8 (white calcareous gyttja, sharp boundary at $372.0 \mathrm{~cm}$ ), 9 (greybrown peat or assembled peat detritus, sharp boundary at $371.5 \mathrm{~cm}$ ), 10 (olivegrey calcareous gyttja, sharp boundary at $370.5 \mathrm{~cm}$ ), and 12 (grey, partly calcareous gyttja with silt and Characeae bands, very sharp boundary at $366 \mathrm{~cm}$ ) (Table 2).

\section{BIO- AND CHRONOSTRATIGRAPHY}

\section{Pitkasoo 3 (Figs. 3-6)}

The lower mineral deposits seems to contain redeposited pollen; Betula is high and Pinus is low. The charcoal curve frequency is high in the bottom part, possibly due to outwash from the till (Fig. 6). A high Betula curve is exchanged for high Pinus values in the lowermost gyttja (unit 1) and peat (unit 2). Some other plants show an abundance too, like the members in the dwarf bushes (Fig. 3). Some of the varia minor and varia major pollen show the same trends like Cyperaceae, Gramineae, Polypodiaceae, Asteraceae liguliflorae, and Equisetum (Fig. 5). The preceding gyttja (unit 3) has a very impressive Betula curve with a subsequent drop in Pinus. At the same time a drop in the dwarf bushes occurs together with minima in almost all other curves. Filipendula starts continuously. The diversity of nonarboreal (NAP) taxa is high.

Pinus increases again in the peat (unit 4) on the expence of Betula which later becomes exchanged for a rapidly dropping Pinus (Fig. 3). The dwarf bushes are low and Artemisia increases. At the same time there is a succession of Filipendula-Galium and Cyperaceae, after which Gramineae and Betula increase towards the unit border where Pediastrum and Botryococcus increase too. A high charcoal curve starts just at the upper unit limit (Fig. 6).

The upper part of the diagram (units 5-12) shows a general growth in the xerophytic plants, but after the expected Alnus level they decrease again. The diversity is high but diminishes with the Alnus immigration, whilst the curves of Ulmus and Betula are rising.

\section{Interpretation}

The lower gyttja (unit 1) exposes high Pinus values and also abundant pollen from the dwarf bushes. Increasing values for Cyperaceae, Equisetum, and Gramineae have been interpreted as coming from the pond where gyttja was forming. The lower peat layer (unit 2) shows increasing birch growth but the pine curve is very high initially. Most probably the peat was formed near an open 


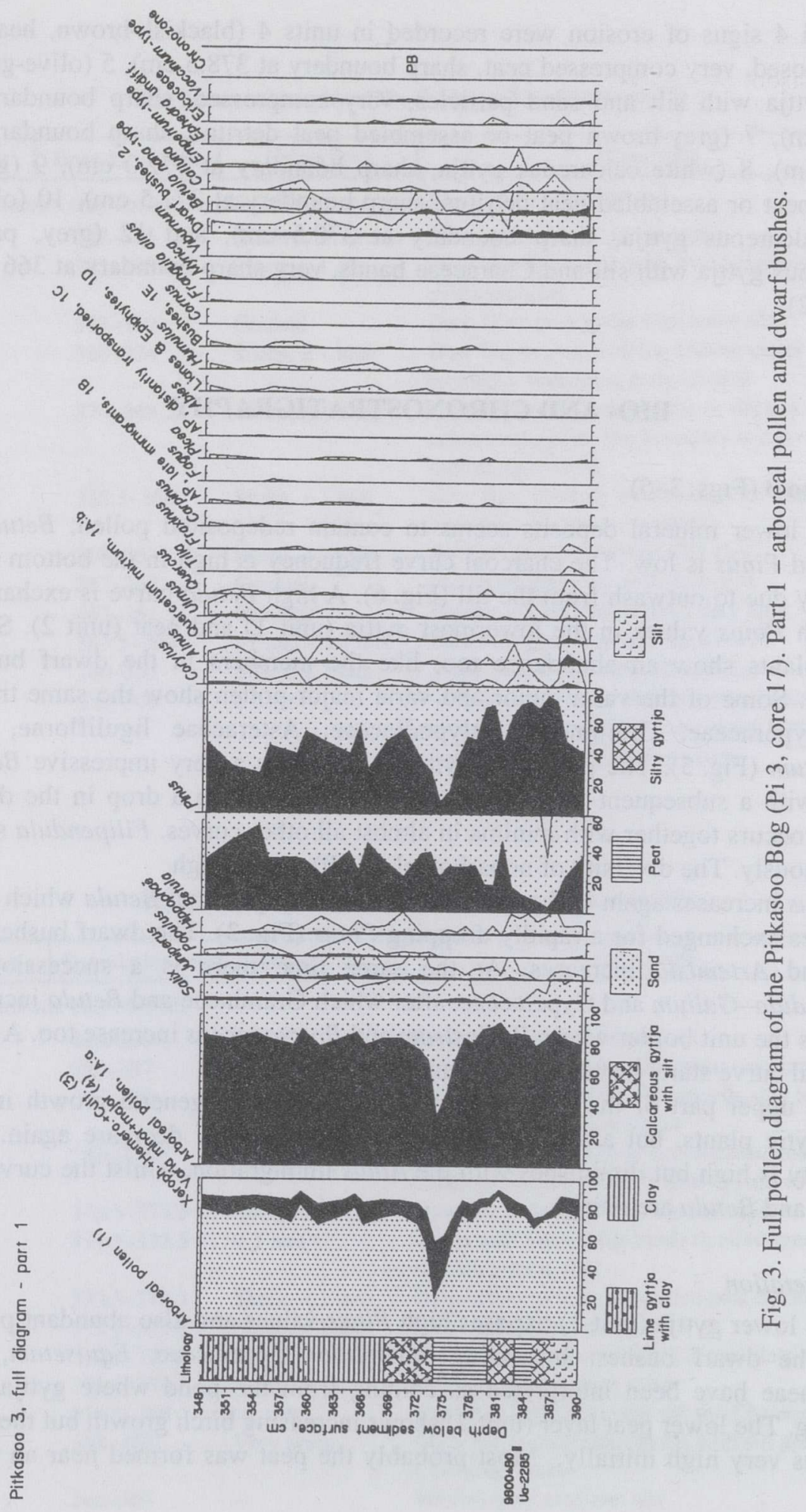




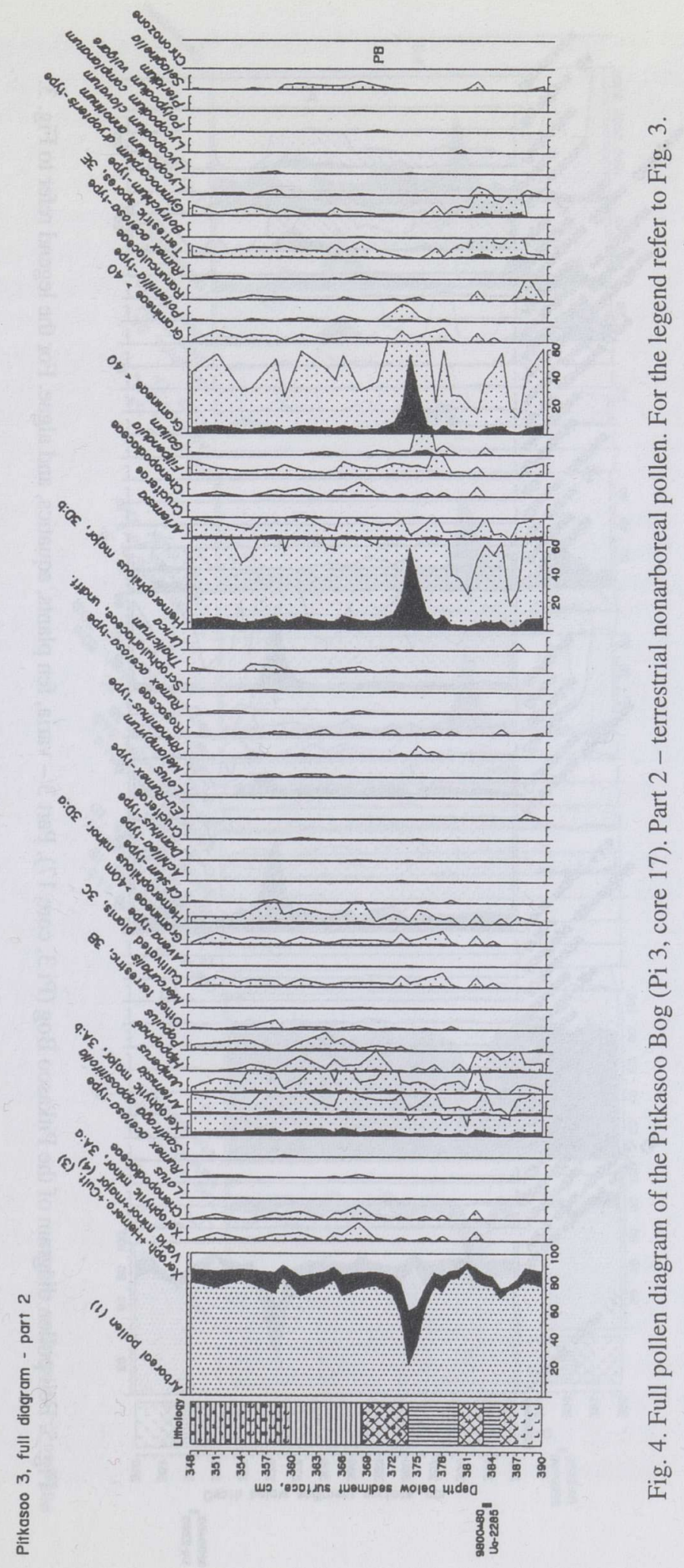




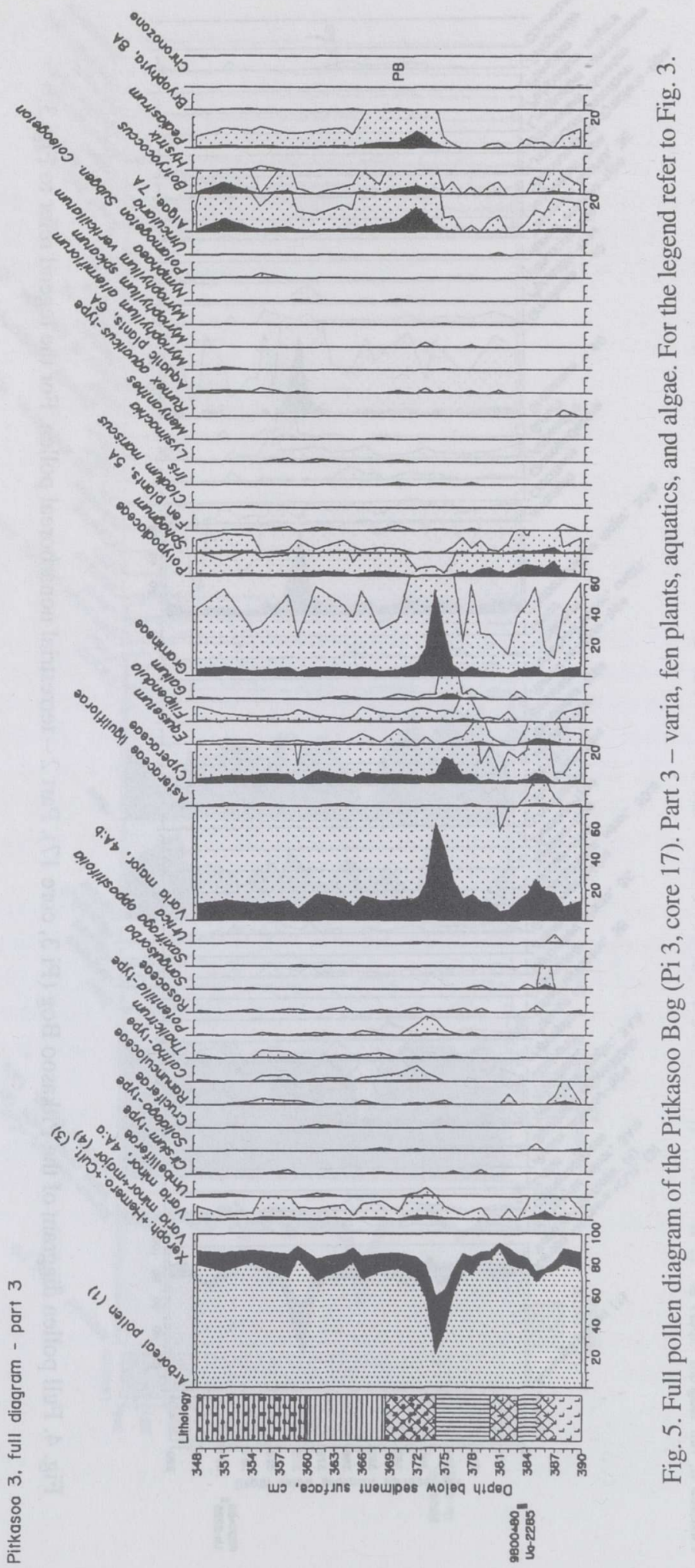




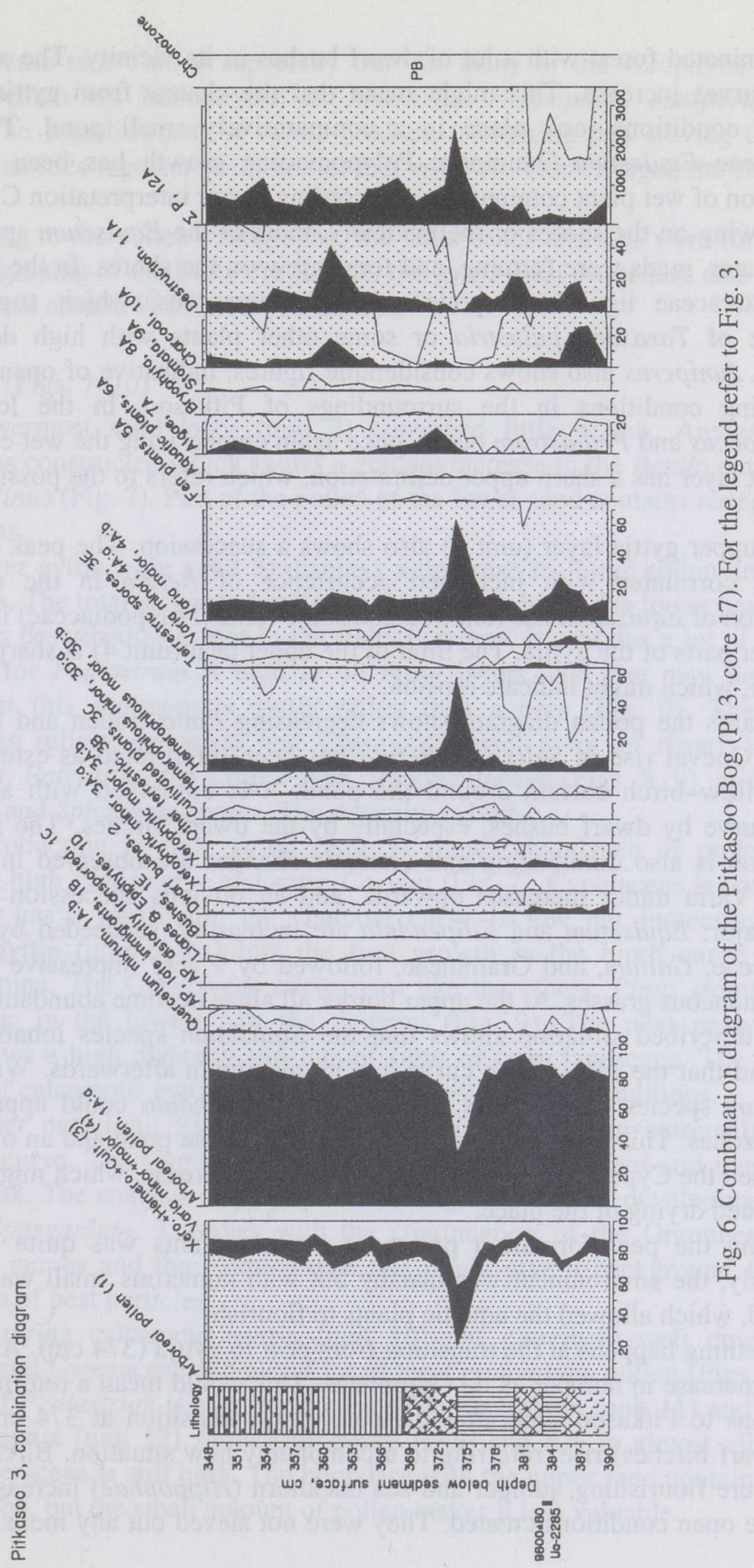


pine-dominated forest with a lot of dwarf bushes in its vicinity. The xerophytic major curves increase. This might mean that the change from gyttja to peatforming conditions took place in a comparatively small pond. The initial Cyperaceae-Equisetum-Gramineae-Polypodiaceae growth has been a natural succession of wet plant communities. According to our interpretation Cyperaceae was growing on the shores or thelmatically, most of the Equisetum spores grew in the water, reeds were forming, and ferns grew on the shores. In the beginning also Asteraceae liguliflorae pollen is quite numerous, which suggests the presence of Taraxaca palustria or some other plants with high demand of wetness. Juniperus also shows considerable figures, indicative of open and light demanding conditions in the surroundings of Pitkasoo. In the lower peat Botryococcus and Pediastrum occur, once again emphasizing the wet conditions. The peat layer has a sharp upper delimitation, which refers to the possibility of a hiatus.

The upper gyttja layer (unit 3) also shows a succession. The peak in growth may be correlated with increased occurrence of Betula in the area. The succession of Equisetum has renewed and some ferns (Polypodiaceae) increase in the upper parts of the gyttja. The limit of the upper peat (unit 4) is sharp and very irregular, which might indicate erosion.

Upwards the pollen diagram shows decreasing Pinus pollen and increasing Betula. Coeval rise in Salix and Betula has been interpreted as establishment of a willow-birch curtain around the pond. It is combined with a decrease in the curve by dwarf bushes, especially by the dwarf birches. The xerotherm vegetation is also diminishing and dramatic changes are observed in the varia curves. Varia minor increases upwards, and an obvious succession occurs in varia major: Equisetum and Filipendula are increasing, succeeded by a rise in Cyperaceae, Galium, and Gramineae, followed by a very impressive growth in the spontaneous grasses. At the upper border all algae become abundant.

The described situation shows that the Equisetum species inhabited drier areas and that the Filipendula curve had its maximum afterwards. Water-living Equisetum species became less frequent and Filipendula could appear in the marshy zones. This gives evidence of a drying up of the pond and an overgrowth of it. Then the Cyperaceae and the Galium species increase, which might refer to a continued drying of the place.

During the peat formation pollen of aquatic plants was quite abundant. Obviously, the environment was marshy but with numerous small water bodies included, which allowed the aquatic plants to flourish.

Something happens at the transition from peat to gyttja $(374 \mathrm{~cm})$. Algae show a great increase in number as do Gramineae. This would mean a return of wetter conditions to Pitkasoo. Just after the peat-gyttja transition at $374 \mathrm{~cm}$, birches (and dwarf birches) rise, referring to a completely new situation. Birches, all of them, were flourishing, juniper and sea buckhorn (Hippophaë) increased due to the more open conditions created. They were not sieved out any more. All other 
curves increase too. This is especially true for many of the xerophytic curves (most of which are heliophytic) as Artemisia, Hippophä̈, Juniperus, and Populus. The establishment of Alnus produces sheltering and sieving through plant communities together with birches and willows. This changed the situation again.

According to the pollen stratigraphy, the basal sands and silts were formed at the very beginning of the Early Pre-Boreal, the gyttja-peat sequences also during the Pre-Boreal around $9800 \pm 80$ (Ua-2285).

\section{Pitkasoo 4 (Figs. 7-10)}

The lowermost sand layer (unit 2) contained little pollen. Anyway, the diagram was constructed which shows a gradual increase in the Betula curve and very high Pinus (Fig. 7). Part of the pollen of the lower sand contains redeposited pollen grains.

The lower gyttja layer (unit 3) displays a decrease in Pinus pollen and high birch pollen. The total amount of pollen in this layer is high. The lower peat layer (unit 4) was described as a peat in the field, however, it contains a lot of gyttja. The curve for Pediastrum is high in all those layers, and one may therefore suggest that this sediment is gyttja rather than a peat (Fig. 9). The close surroundings reflect Artemisia and Chenopodiaceae, a lot of dwarf bushes, Filipendula, Potentilla, the Caltha-type, Ranunculaceae (Figs. 8, 9), and some Selaginella and Sphagnum spores. The diversity is high.

The introduction to lime gyttja (unit 5) shows abundance of pollen too, especially a high Pinus curve and some Corylus (Fig. 7). Cyperaceae is common. Pediastrum has a maximum, the charcoal curve is low but increasing. The overlying gyttja (unit 6) exhibits the first growth in the birch curve and a decline of pine. The Cyperaceae curve rises like the others. Pinus stomata are characteristic in the lowest part the diagram (Fig. 9). The next peaty layer (unit 7) shows a high diversity and lots of signs of open landscape. The pollen frequency of calcareous gyttja (unit 8) also emphasizes open conditions.

The upper peat (unit 9) has an impressive Betula and an extremely high Gramineae curve. The Cyperaceae and Pediastrum are abundant and there is a charcoal peak. The analysis displayed a rather high and further developing curve of Typha-Sparganium. Together with the continuation of the Gramineae and Cyperaceae curves and the Festuca-type this might give a background for the assemblance of peat particles.

The overlying calcareous gyttja (unit 10) has extremely well developed Gramineae and Cyperaceae and also a lot of the Festuca-type pollen (Figs. 8, 9). The share of Pediastrum is also remarkable. The lime gyttja (unit 11) and upper calcareous gyttja (unit 12) show a dropping Pinus and rise in almost all other curves. Cyperaceae is still high. The boundary with the upper sand contains a lot of information, but the small amount of pollen makes it less valuable. 


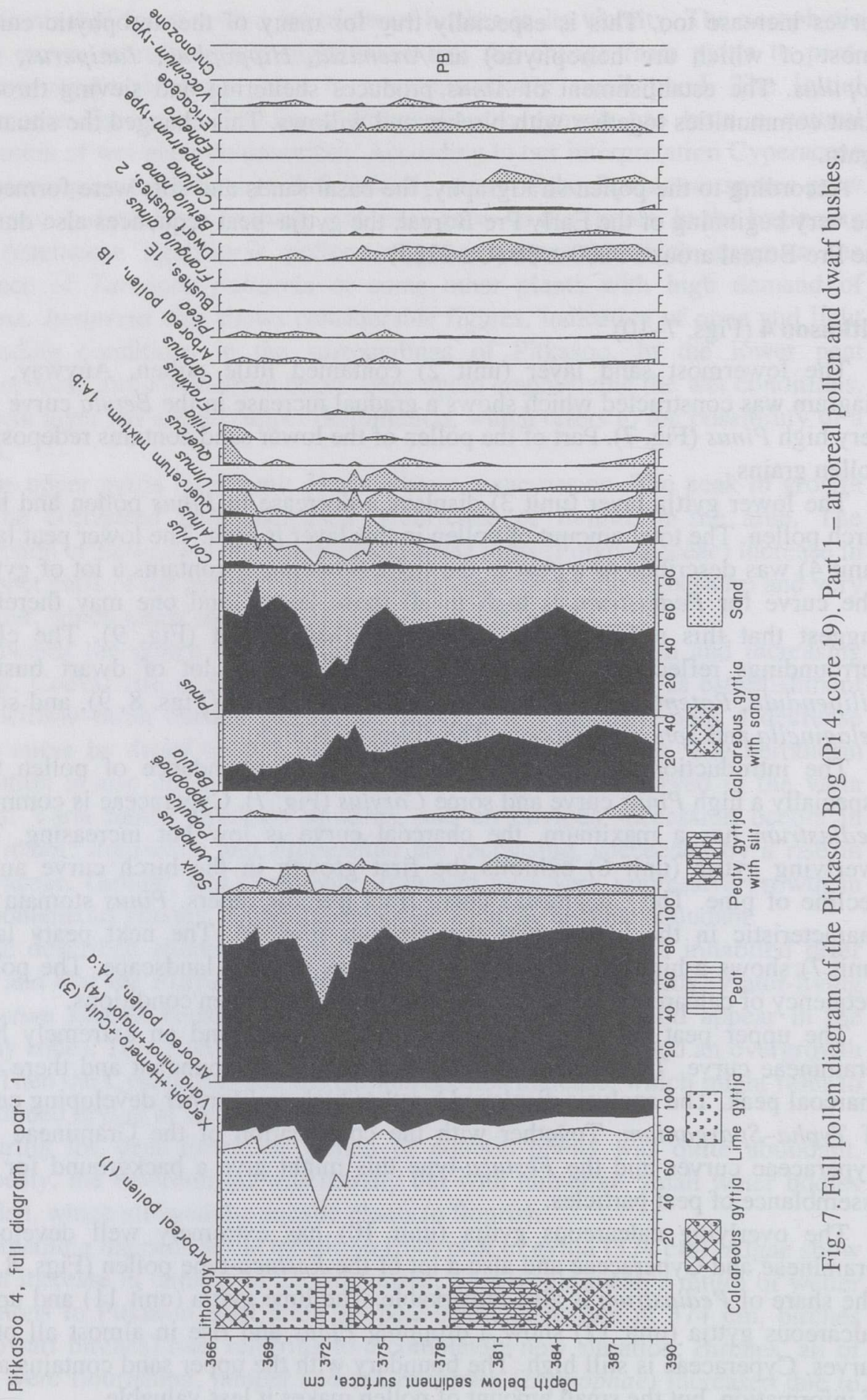




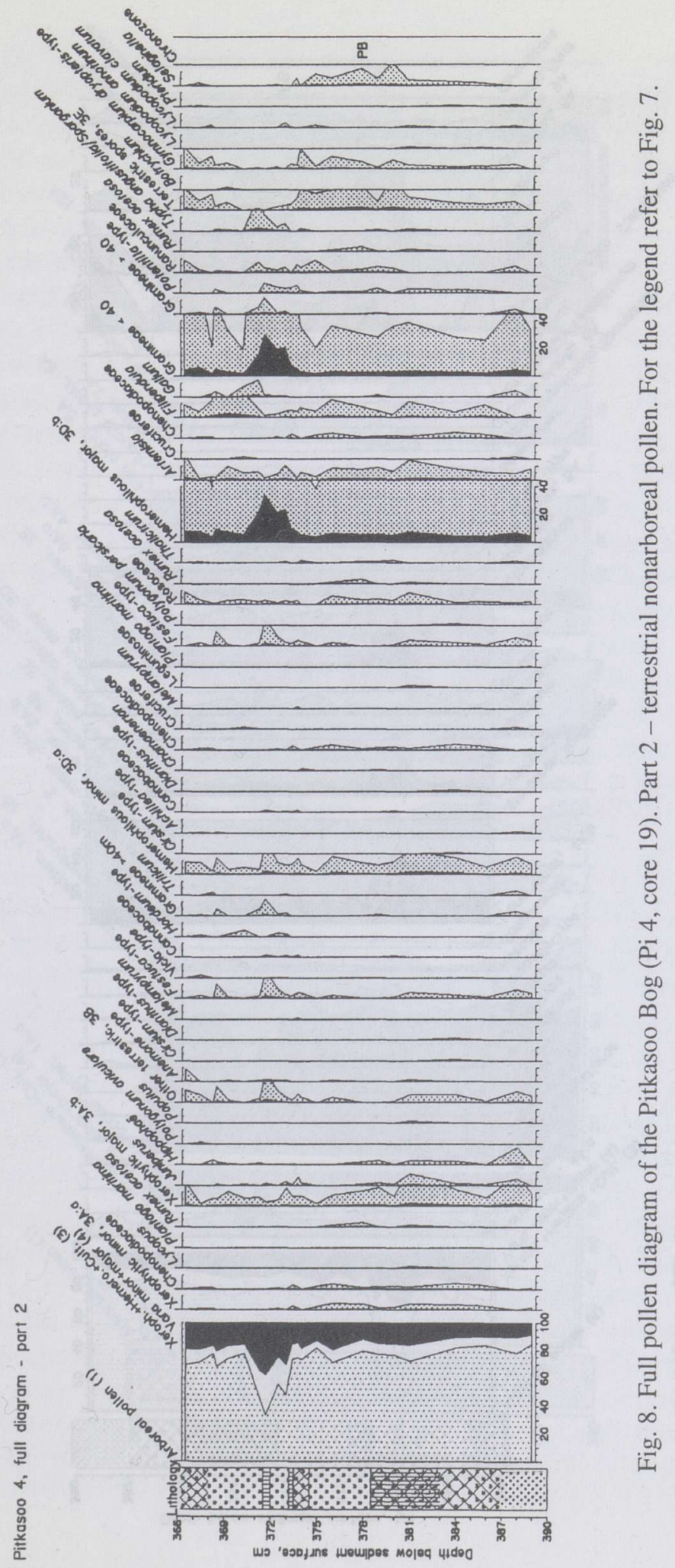




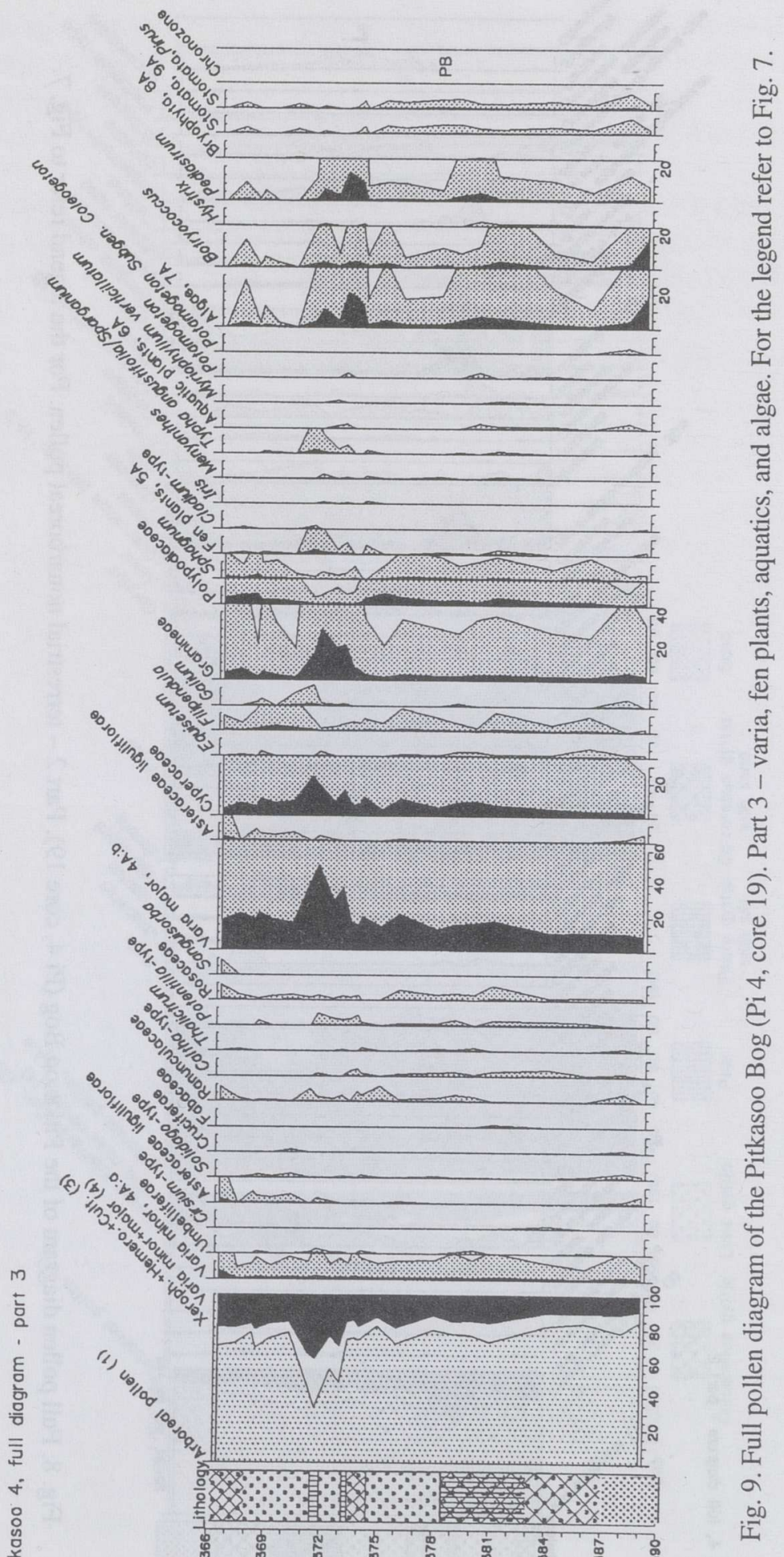




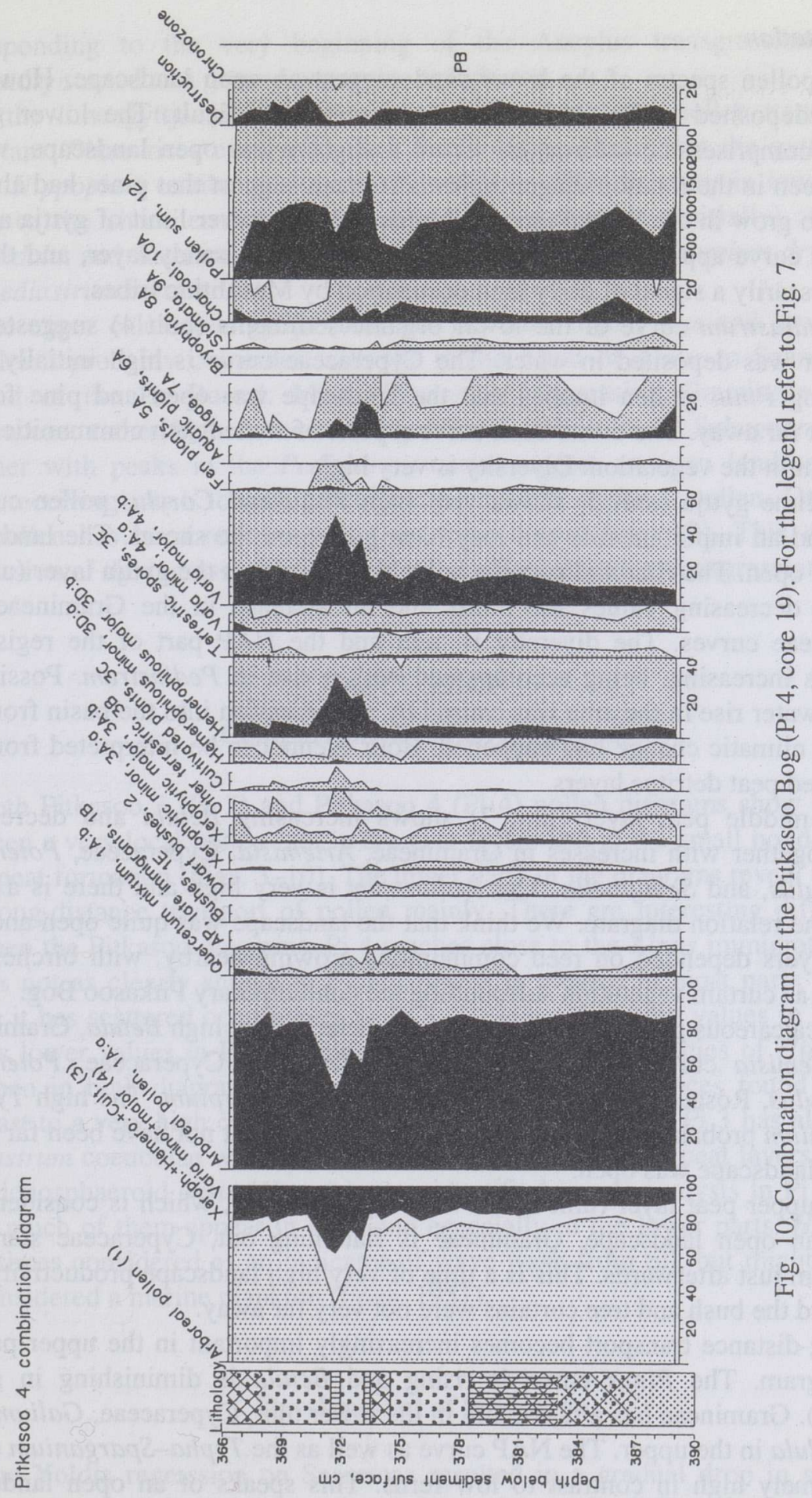


The pollen spectra of the lower sand suggest an open landscape. However, much redeposited pollen makes the interpretation difficult. The lower gyttja (unit 3) comprises the information about a slightly less open landscape, which can be seen in the relation diagram. Pinus stomata suggest that pines had already started to grow in the West Saaremaa Upland. At the lower limit of gyttja a high charcoal curve appears which may be connected with a sandy layer, and thus is not necessarily a signal of early land occupation by Mesolithic tribes.

A Pediastrum curve of the lower organic sediments (unit 4) suggests that the layer was deposited in water. The Cyperaceae curve is high initially. The increasing Pinus pollen implies that the landscape was open and pine forests were not far away. The dwarf bush curve reports of some heath communities still important in the vegetation. Diversity is very high.

The lime gyttja (unit 5) shows very high Pinus and Corylus pollen curves. Ferns had an important role and may have grown on the shores. The landscape was still open. The charcoal curve is quite high. Upwards the gyttja layer (unit 6) exposes decreasing values for Pinus and an increase in the Gramineae and Cyperaceae curves. The diversity is high and the NAP part of the registered pollen is increasing, being accompanied with a rise in Pediastrum. Possibly a ground water rise in the area was caused by an ingression into the basin from the sea or a climatic change had happened. Both events can be interpreted from the assembled peat detritus layers.

The middle peat layer (unit 7) shows increasing Betula and decreasing Pinus together with increases in Gramineae, Artemisia, Cyperaceae, Potentilla, Ranunculus, and Selaginella. The Pediastrum is very high and there is a NAP rise in the relation diagram. We think that the landscape was quite open and that peaty layers depended on reed communities growing nearby, with birches and willows as curtain vegetation surrounding the contemporary Pitkasoo Bog.

The calcareous gyttja layer (unit 8) is characterized by high Betula, Gramineae, and Artemisia curves which appeared together with Cyperaceae, Potentilla, Ranunculus, Rosaceae, the Festuca-type, and Gymnocarpium. The high TyphaSparganium probably gives the hint that the shores might not have been far away and the landscape was open.

The upper peat layer (unit 9) shows a high diversity, which is considered to reflect an open landscape. Gramineae is flattening out, Cyperaceae starts its maximum just afterwards. This is a time of very high landscape productivity, the reeds and the bush and tree curtains were not very far away.

Long-distance transport becomes increasingly important in the upper part of the diagram. The Pinus curve is rising and Betula is diminishing in gyttja (unit 10). Gramineae has a maximum in the lower unit, Cyperaceae, Galium, and Filipendula in the upper. The NAP curve as well as the Typha-Sparganium curve is extremely high in contrast to low ferns. This speaks of an open landscape 
corresponding to the very beginning of the Ancylus transgression which assumedly started as a ground water rise at Pitkasoo.

In the lime gyttja (unit 11) long-distance and regional pollen transport is important. Pinus rises even more and Betula drops throughout the gyttja unit. Some Hippophaë exhibit a rise, as does willow. The diversity is low, which refers to the shore environment and includes Artemisia (initially), Galium, Filipendula, and Asteraceae liguliflorae. Polypodiaceae, Gymnocarpium dryopteris, and Pediastrum increase.

The upper calcareous gyttja (unit 12) indicates high Pinus and low Alnus. This level probably coincides with the introduction of Alnus to Saaremaa at the end of the Pre-Boreal. Much Hippophae,, increasing Gramineae, stable Cyperaceae, rather high Asteraceae liguliflorae, and a lot of Sphagnum spores together with peaks in the Pediastrum curve suggest an open landscape (the mire) receiving much long-distance transported and regional pollen. Only very few pollen has been registered in the topmost sand (unit 13). This gives an impression of the ingressive landscape and the final Ancylus transgression.

\section{DISCUSSION}

\section{Comparison of pollen diagrams}

Both Pitkasoo 3 ( $\mathrm{Pi}$ ) and Pitkasoo 4 ( $\mathrm{Pi}$ 4) pollen diagrams show changes between a very local pollen rain in the peat layers and in the small ponds before each peat formation (Figs. 3-10). The upper parts of the diagrams reveal regional and long-distance transport of pollen mainly. There are interesting differences between the Pitkasoo diagrams. Pi 4 reaches close to the Alnus immigration, but this is not as clearly shown in Pi 3. Corylus is present in most parts of $\mathrm{Pi} \mathrm{4,}$ while it has scattered occurrences in Pi 3. Juniperus has high values in Pi 3 but shows lower values in Pi 4. Almost continuous high frequencies of Hippophä are seen in both diagrams. Some few Betula nana occurrences found in $\mathrm{Pi} 4$ contrast to a very high curve in $\mathrm{Pi}$ 3. The lower peat layer in $\mathrm{Pi} 3$ has almost no Pediastrum coenobiae whilst much Pediastrum occurs in the peat layers in Pi 4. Hystrichosphaeroid cysts (Hystrix) were identified in one analysis in Pi 3 while quite much of them appear in $\mathrm{Pi} \mathrm{4,and} \mathrm{especially} \mathrm{in} \mathrm{the} \mathrm{lower} \mathrm{parts.} \mathrm{Hystrix} \mathrm{is}$ sometimes considered as an indicator of wave wash from till, but might as well be considered a marine plankton (Fries, 1951).

\section{Development of landscape}

The Yoldia regression on Saaremaa resulted in a gradual drop in sea level between the glaciofluvial ridge and the slope of the upland. First the lagoon, then 
an isolated lake was formed, which due to gradual water level lowering turned into a small pond. Under clayey deposits peat and gyttja accumulated twice and there are evidences of limnic conditions later on. The organic layer is underlain by sand and gravel which rest directly on the washed till. A lower peat at $385 \mathrm{~cm}$ is dated to $9800 \pm 80 \mathrm{BP}$ (Ua-2285). The originally marine plankton Hystrix (Hystrichosphaeroid cysts) was identified and several shore plants appear. Possibly two ground water rises occurred before the lake became overgrown by thelmatic fen vegetation. The upper peat limit at $21.5-22.5 \mathrm{~m}$ roughly estimates the lowest Yoldia level here. As the Yoldia maximum shore displacement is at $32 \mathrm{~m}$, this yields a magnitude of the Yoldia regression of some $10-11 \mathrm{~m}$.

The earliest part of the Ancylus transgressional sediments were identified as clay overlain by a peat-gyttja bed. Contemporaneously with the clay deposition, a huge spit, $3 \mathrm{~km}$ in length and $100-150 \mathrm{~m}$ wide was formed east of Pitkasoo. It is one of the most representative Ancylus transgression formations on Saaremaa Island (Kessel \& Raukas, 1967). Spit texture and structure show that the PreAncylus glaciofluvial ridge occurring in the core of the spit was covered by beach deposits with a mollusc fauna, containing Limnaea peregra, Ancylus fluviatilis, Pisidium, and Bithynia (Kessel \& Raukas, 1967). This spit closed the connection between the lagoon and the Ancylus Lake and dammed up the lake in the Pitkasoo basin with a threshold elevation of about $27.5-28.0 \mathrm{~m}$. The lake was larger and lasted longer than the previous one. First lime gyttja, then gyttja was deposited, both rich in macroremains, indicating that the lake was filling up with sediments.

The Ancylus transgression started about $9600-9500$ BP, which is in good accordance with the records obtained from the other parts of Estonia (Heinsalu \& Veski, 1991; Saarse et al., 1990, 1997) and also from the neighbouring countries (Berglund, 1964; Königsson, 1968; Eronen, 1976; Eronen \& Haila, 1982; Svensson, 1989, 1991; Björck, 1995; etc.).

Judging by the elevation of the Yoldia Sea minimum and the Ancylus Lake maximum water level, sea level rose about $8 \mathrm{~m}$ during the Ancylus transgression and reached $30 \mathrm{~m}$ a.s.l. The duration of the Ancylus transgression is not exactly dated as the isolation contact lies between clay and lime gyttja. However, according to regional pollen stratigraphy (Saarse et al., 1990, 1994; Saarse \& Königsson, 1992), the Betula PAZ is dated to 9500-9000 BP (Raukas et al., 1995). So, the lime gyttja presumably started to accumulate around 9000 BP. A similar date has been derived from the Järvesoo Bog sequence (Saarse, 1994). Järvesoo is also an ancient Ancylus lagoon, located $2 \mathrm{~km}$ southwest of Pitkasoo and having a similar development. The radiocarbon date of $8800 \pm 80 \mathrm{BP}$ (TA-782) from lacustrine lime near the isolation contact at Järvesoo defines the age of the isolation during the Ancylus regression. By that time the Ancylus transgression was over and its level had decreased to the Järvesoo threshold at $27.5 \mathrm{~m}$ a.s.l. 


\section{CONCLUSIONS}

1. The Pitkasoo Bog is a transgressional basin with the following sediment lithofacies:

(a) peat and peaty gyttja lacking diatoms (Heinsalu, pers. comm.), formed during the regressional phase of the Yoldia Sea;

(b) Ancylus transgressional spit deposits with typical Ancylus molluscs (Kessel \& Raukas, 1967);

(c) transgressional Ancylus lagoonal clay which is rather thick and widespread.

The bedding conditions of these deposits estimate the magnitude of the Yoldia regression as $10-11 \mathrm{~m}$ or more and the Ancylus transgression to $c .8 \mathrm{~m}$ in the vicinity of Pitkasoo.

2. The lower parts of both Pitkasoo pollen diagrams (covering the Yoldia regressional phase) show changes between a very local pollen rain in the buried peat and gyttja layer, because a very small water body was left at Pitkasoo. The upper parts of the diagrams (covering the Ancylus transgressional phase) show regional and long-distantly transported pollen as Pitkasoo became part of a large lake.

3. Pitkasoo was isolated at two times from the Baltic Sea according to the lithostratigraphic records: first during the Yoldia regression at about $9800 \mathrm{BP}$, and for a second time during the Ancylus transgression before the Alnus immigration to Saaremaa.

\section{ACKNOWLEDGEMENTS}

The authors thank Anto Raukas and Avo Miidel, Tallinn, Estonia, for valuable comments and reading the manuscript. Ivan Lundvall, Uppsala, Sweden, made the pollen analysis and Edward Ledwaba, Uppsala, Sweden, prepared the samples for analysis and fed the material into the computer. Siim Veski, Tallinn and Uppsala, compiled the diagrams. People working with us in the field are cordially thanked. Financial support was provided by the Estonian Science Foundation, grant No. 1958, the Royal Swedish Academy of Sciences, and the University of Uppsala, Sweden.

\section{REFERENCES}

Berglund, B. E. 1964. The Post-Glacial Shore Displacement in Eastern Blekinge, Southeastern Sweden. Sver. Geol. Unders., C 599.

Björck, S. 1995. A review of the history of the Baltic Sea, 13.0-8.0 ka BP. Quat. Int., 27, 19-40.

Eronen, M. 1976. A radiocarbon-dated Ancylus transgression site in south-eastern Finland. Boreas, $5,65-67$. 
Eronen, M. \& Haila, H. 1982. Shoreline displacement near Helsinki, southern Finland during the Ancylus stage. Ann. Acad. Scient. Fenn., A II, 134, 111-138.

Fries, M. 1951. Pollenanalytiska vittnesbörd om senkvartär vegetationsutveckling, särskilt skogshistoria, i nordvästra Götaland. Acta Phytogeogr. Suec., 29.

Haila, H. \& Raukas, A. 1992. Ancylus Lake. In Geology of the Gulf Finland (Raukas, A. \& Hyvärinen, H., eds.). Estonian Academy of Sciences, Tallinn, 283-296.

Heinsalu, A. \& Veski, S. 1991. Ermistu järve arengust. In Inimene ja geograafiline keskkond (Saarse, L., ed.). Eesti Teaduste Akadeemia, Tallinn, 14-18.

Kessel, H. 1961. Balti mere arenemisest Eesti NSV territooriumil holotseenis. ENSV TA Geoloogia Instituudi Uurimused, VII, 167-185.

Kessel, H. 1988. Drevneberegovye obrazovaniya ostrova Saaremaa. In Geologicheskoe stroenie $i$ razvitie Baltijskogo morya $i$ zakonomernosti formirovaniya mineral'nykh resursov (Raukas, A., ed.). Institute of Geology, Tallinn, 110-114 (in Russian).

Kessel, H. \& Punning, J.-M. 1969. Über die Verbreitung und Stratigraphie der Sedimente des Joldiameeres in Estland. Eesti NSV TA Toim. Keemia. Geol., 18, 2, 154-163 (in Russian).

Kessel, H. \& Raukas, A. 1967. The Deposits of the Ancylus Lake and Littorina Sea in Estonia. Valgus, Tallinn (in Russian).

Kessel, H. \& Raukas, A. 1979. The Quaternary history of the Baltic. Estonia. In The Quaternary History of the Baltic (Gudelis, V. \& Königsson, L.-K., eds.). Acta Universitatis Upsaliensis. Symposia Universitatis Upsaliensis Annum Quingentesimum Celebrantis, Vol.1. Uppsala, 127-146.

Königsson, L.-K. 1968. The Ancylus transgression in the Skede Mose area, Öland. Geol. Fören. Stockh. Förh., 90, 5-36.

Königsson, L.-K. \& Poska, A. Pitkasoo - a West Estonian Holocene reference site. Proc. Estonian Acad. Sci. Geol. (in press).

Königsson, L.-K., Saarse, L. \& Veski, S. 1998. Holocene history of vegetation and landscape on the Kõpu Peninsula, Hiiumaa Island, Estonia. Proc. Estonian Acad. Sci. Geol., 47, 1, 3-19.

Lepland, A., Miller, U. \& Sakson, M. 1995. Palaeoenvironmental conditions during the Baltic Yoldia stage in the Tallinn area, Northern Estonia. Quat. Int., 27, 83-94.

Poska, A. 1994. Three Pollen Diagrams from Coastal Estonia. Licentiat thesis. Kvartärg. Avd., Upps., 170.

Raukas, A. 1994. Yoldia stage - the least clear interval in the Baltic Sea history. Baltica, 8, 5-14.

Raukas, A. 1995. Evolution of the Yoldia Sea in the Eastern Baltic. Quat. Int., 27, 99-102.

Raukas, A., Saarse, L. \& Veski, S. 1995. A new version of the Holocene stratigraphy in Estonia. Proc. Estonian Acad. Sci. Geol., 44, 4, 201-210.

Saarse, L. 1994. Bottom Deposits of Small Estonian Lakes. Estonian Academy of Sciences, Tallinn (in Russian).

Saarse, L., Heinsalu, A., Poska, A., Veski, S., Rajamäe, R., Hiie, S., Kihno, K. \& Martma, T. 1997. Early Holocene shore displacement of the Baltic Sea east of Tallinn (N. Estonia). Baltica, 10, 13-24.

Saarse, L. \& Königsson, L.-K. 1992. Holocene environmental changes on the Island of Saaremaa, Estonia. PACT, 37, 97-131.

Saarse, L., Veski, S., Königsson, L.-K. \& Poska, A. 1994. An outline of the Estonian Quaternary geology. In The Silurian and Quaternary Geology of the Island of Saaremaa, Estonia. Estonian Academy of Sciences, Tallinn, 27-49.

Saarse, L., Vishnevskaya, Ye., Sarv, A., Rajamäe, R. \& Ilves, E. 1990. Evolution of the lakes of Saaremaa Island. Proc. Estonian Acad. Sci. Biol., 39, 1, 34-45 (in Russian).

Svensson, N.-O. 1989. Late Weichselian and Early Holocene Shore Displacement in the Central Baltic, Based on Stratigraphical and Geomorphological Records from Eastern Småland and Gotland, Sweden. PhD thesis, University of Lund, 25. 
Svensson, N.-O. 1991. Late Weichselian and Early Holocene shore displacement in the Central Baltic Sea. Quat. Int., 9, 7-26.

Troels-Smith, J. 1955. Characterization of Unconsolidated Sediments. Danm. Geol. Unders., IV. Rakke, 3, 10.

\section{PITKASOO - ANTSÜLUSJÄRVEST ERALDUNUD LAGUUN SAAREMAAL}

\section{Lars-König KÖNIGSSON, Leili SAARSE ja Göran POSSNERT}

Pitkasoost leiti hiljuti savikate setete alla mattunud turba- ja järvemudakihid, mille teke algas Joldiamere regressioonil, umbes 9800 aastat tagasi. Need sisaldasid valdavalt väga lokaalset õietolmu, mistõttu ka õietolmuspektrite varieeruvus oli küllaltki suur. Lasuvad savikad setted on kuhjunud Antsülusjärve transgressiooni käigus. Neis sisalduv õietolm on nii regionaalne kui ka kaugsissekandest pärinev. Stratigraafilisele materjalile tuginedes oletatakse, et Pitkasoo isoleerus Läänemerest esmalt Joldiamere regressiooni ajal ja lõplikult Antsülusjärve transgressiooni ajal maakoore neotektoonilise kerke tulemusel. Turba ja järvemuda vaheldumine näitab, et Joldiamere regressiooni ajal tekkinud väikeses järves veetase muutus. Põhjuseks võisid olla kas sademetehulga mõningane suurenemine ja sellega seoses ka põjaveetaseme tõus või siis muutused meretasemes.

\section{БОЛОТО ПИТКАСОО - АНЦИЛОВАЯ ЛАГУНА НА ОСТРОВЕ СААРЕМАА, ЭСТОНИЯ}

\section{Ларс-Кёниг КЁНИГССОН, ЛейЛи СААРСЕ и Гёран ПОССНЕРТ}

В болоте Питкасоо найдены погребенные под глинистыми отложениями торф и сапропель, формирование которых началось одновременно с регрессией Иольдиевого моря, примерно 9800 лет т. н. В органогенных отложениях преобладают пыльца и споры местных растений. Накопление покрывающих органогенные отложения глин происходило во время трансгрессии Анцилового озера. Эти отложения содержат пыльцу не только регионального характера, но и привнесенную извне. Стратиграфический материал подтверждает вывод о том, что изоляция Питкасоо от Балтийского моря началась в ходе регрессии Иольдиевого моря и завершилась во время трансгрессии Анцилового озера, произошедшей в результате поднятия земной коры. Чередование сапропеля и торфа в отделившемся от моря озере указывает на изменение в нем уровня воды в раннем пребореале. Причина кроется либо в увеличении осадков, а значит, и в повышении уровня грунтовых вод, либо в изменении уровня моря. 